Ann. Biol. anim. Bioch. Biophys., 1978, 18 (2 B) 317-325.

\title{
The role of the sex chromosomes in mammalian germ cell differentiation
}

\author{
by P. S. BURGOYNE
}

Department of Obstetrics and Gynaecology, University of Edinburgh, 23 Chalmers Street, Edinburgh EH3 9EW, U. K.

\begin{abstract}
Summary. An analysis is presented of the relationship between abnormalities of mammalian germ cell differentiation and their sex-chromosomal make-up. It is concluded that germ cells in an ovary require two functional $X$ chromosomes for optimal development. The effects of $X$-dosage deficiency are most severe in species where there is a long period of time between the formation and utilisation of the oocytes. Thus the ovaries of XO (Turner's syndrome) and $X Y$ women are almost invariably devoid of oocytes. Germ cells in the testis on the other hand, must have only one $X$ chromosome if they are to survive. Consequently adult $X X$ and $X X Y$ males have sterile testes.
\end{abstract}

Ohno (1969) has presented evidence that the genetic content of the sex chromosomes has been conserved during the evolution of the mammals. Students of sex chromosome function are therefore in the enviable position of being able to expect essentially similar sex chromosomal effects in all mammalian species. It is the aim of the present paper to draw some general conclusions about the consequences of sex chromosome activity in the germ cells of eutherian mammals.

In 1961 Lyon put forward convincing arguments for there being only one functional $X$ chromosome in the cells of female mammals. However, Ohno and coworkers found that both $X$ chromosomes were euchromatic (indicating functional capacity) in oogonia and oocytes from fetal ovaries of the rat, hamster, human and mouse (Ohno, Kaplan and Kinosita, 1961 ; Ohno and Weiler, 1961 ; Ohno, Klinger and Atkin, 1962 ; Ohno, 1963). Recent biochemical observations have confirmed that both Xs are functional in oocytes (Epstein, 1969 ; 1972 ; Gartler ef al., 1972 ; Gartler, Liskay and Gant, 1973 ; Kozak, McLean and Eicher, 1974 ; Gartler, Andina and Gant, 1975 ; Mangia, Abbo-Halbach and Epstein, 1975) and probably also in oogonia (Migeon and Jelalian, 1977). Thus, female germ cells do not conform to Lyon's hypothesis of $X$ dosage compensation, both $X$ chromosomes being functional throughout most of their lifespan. As will become evident later, both $X$ s are also functional in $X X$ germ cells which have colonised a testis.

In the following sections, the role of the sex chromosomes in germ cell differentiation will be assessed by following the fate of $X O$ and $X Y$ germ cells in an ovary, and of $X X, X O$ and $X X Y$ germ cells in a testis. 


\section{The sex chromosomes and germ cell fate in an ovary}

XO germ cells in an ovary.

It is well known that $X O$ women are typically sterile, their ovaries lacking both oocytes and follicles. Germ cells are, however, present in the ovaries of $X O$ fetuses (Singh and Carr, 1966). Germ cell loss begins late in fetal life, and few oocytes remain by the time of birth (Carr, Haggar and Hart, 1968). Jirásek (1977) has observed that there is incomplete enclosure of the oocytes by the developing follicles in XO fetuses, and suggests that this is the cause of the subsequent oocyte loss. Burgoyne (1978) on the other hand, has argued that the genetic basis for $X O$ gonadal dysgenesis is the $X$-dosage deficiency in the oocytes. These two points of view are not mutually exclusive : $X$-dosage deficient oocytes may induce poor follicular development, and this in turn may accelerate the processes leading to oocyte death.

In contrast to $X O$ women, $X O$ mice are fertile. Nonetheless, two studies have shown that they also are subject to considerable reproductive impairment. Thus Lyon and Hawker (1973) found that the reproductive lifespan of XO mice was markedly reduced due to premature exhaustion of the supply of oocytes; while Burgoyne and Biggers (1976) have shown that the development of preimplantation embryos from $X O$ mice in vitro is severely impaired. Apparently, $X$-dosage deficiency impairs the health of the oocytes, shortening their lifespan and reducing the viability of the embryos they generate.

The authors of both these studies went on to suggest that the important difference between $X O$ mice and women may be one of timescale ; $X O$ mice reaching puberty before $X$-dosage deficiency effects in the oocytes become severe, $X O$ women reaching puberty after all oocytes have degenerated. The available data on ovarian morphology and fertility for other mammalian XOs is consistent with this hypothesis ; XOs from species with a short generation time being fertile, while those from species with a much longer generation time are sterile (table 1).

TABLE 1

Fertility status and ovarian morphology of mammalian XOs

\begin{tabular}{|c|c|c|c|}
\hline Species & Fertility status & Ovarian morphology & References \\
\hline $\begin{array}{l}\text { Human } \\
\text { Rhesus monkey } \\
\text { Horse }\end{array}$ & Sterile & Streak ovaries & $\begin{array}{l}\text { Review. Simpson, } 1976 \\
\text { Weiss et al., } 1973 \\
\text { Chandley ef al., } 1975 \text {; } \\
\text { Hughes ef al., } 1975\end{array}$ \\
\hline Cat (4 day old) & 一 & $\begin{array}{c}\text { Oocytes and follicles } \\
\text { present }\end{array}$ & Norby ef al., 1974 \\
\hline $\begin{array}{l}\text { Black rat } \\
\text { Mole rat } \\
\text { Wood lemming } \\
\text { Field mouse } \\
\text { House mouse }\end{array}$ & $\begin{array}{l}\text { Fertile or } \\
\text { presumptively fertile }\end{array}$ & $\begin{array}{c}\text { Oocytes and follicles } \\
\text { present }\end{array}$ & $\begin{array}{l}\text { Yong, } 1971 \\
\text { Sharma and Raman, } 1971 \\
\text { Gropp et al., } 1976 \\
\text { Bianchi and Contreras, } 1967 \\
\text { Cattanach, } 1962\end{array}$ \\
\hline
\end{tabular}


$X Y$ germ cells in an ovary.

$X Y$ germ cells in the fetal testis can enter a « female-type » meiosis in response to the meiotic inducer produced by the fetal ovary (Byskov and Saxén, 1976 ; $O$ and Baker, 1976), but these meiotic cells soon genenerate. The question to be discussed here, is whether such meiotic $X Y$ germ cells will survive and form functional oocytes if they are present in an ovary.

In the human there is an inherited condition in which genetic males differentiate as females (Goldstein and Wilson, 1974). These $X Y$ women have streak ovaries just like $X O$ women, and it can again be argued that this is a consequence of $X$-dosage deficiency in the oocytes (Burgoyne, 1978). In the mouse, $X$-dosage deficiency does not lead to sterility ( $X O$ mice are fertile), so that in contrast to the human, $X Y$ germ cells in mice should be able to form functional oocytes. As yet no female $X Y$ mice have been identified, but some important information has been obtained from two adult $X X \leftrightarrow X Y$ chimaeric female mice. (NB Most $X X \leftrightarrow X Y$ mice develop as males see section on $X X$ germ cells in a testis.) Thus Ford ef al. (1975) obtained a male mouse which had received its $Y$ chromosome from its $X X \leftrightarrow X Y$ mother ; while Evans, Ford and Lyon (1977) identified an $X Y$ oocyte from the ovary of another $X X \leftrightarrow X Y$ female. At first sight these observations seem to confirm the expectation that $X Y$ oocytes will be functional. However, the male described by Ford ef al. (1975) had

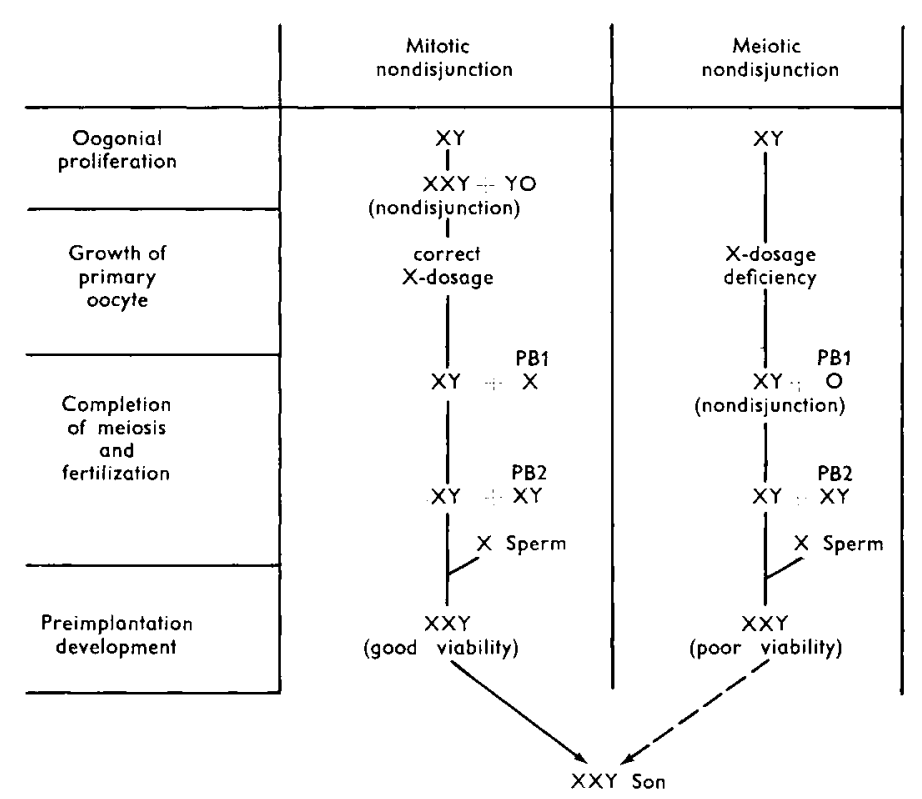

FIG. 1. - Mitotic and meiotic nondisjunction as alternatives for generating an $X X Y$ son from an $X X \mapsto X Y$ mother. PB1, first polar body; PB2, second polar body. Note that mitotic nondisjunction restores the $X$-dosage to normal before the growth phase of the oocyte, so that a normally viable $X X Y$ embryo should result. In contrast, the $X X Y$ embryo produced following meiotic nondisjunction will probably be at a disadvantage when in competition with embryos from $X X$ oocytes. 
the rare karyotype $X X Y$, which raises some important questions. If, as seems certain, this male arose by the fertilization of an $X Y$ egg by an $X$ sperm, then the $X Y$ egg could have arisen by mitotic (oogonial) or meiotic nondisjunction (fig. 1). Burgoyne and Biggers (1976) favoured nondisjunction at an oogonial stage because the resulting $X X Y$ oocyte would have the correct $X$-dosage. This would increase the chances for survival of the $X X Y$ embryo, which must compete with embryos from healthy $X X$ oocytes. The alternative possibility of a meiotic error is tentatively supported by Evans, Ford and Lyon (1977) because the $X Y$ oocyte they identified had the $X$ and $Y$ as univalents at metaphase 1. (This would facilitate a meiotic error.) However, the observed $X-Y$ separation could be a technical artefact, since this is not an uncommon feature of «air dried » first metaphase preparations from spermatocytes.

Germ cells in an ovary - conclusions.

It is concluded that germ cells in an ovary require two functional $X$ chromosomes for optimal growth and development. Germ cells with only a single $X$ are lost from the human ovary long before puberty; but in the mouse, with its short generation time, $X$-dosage deficiency leads only to reduced fertility and a shortened reproductive lifespan. Despite unresolved questions, it can also be concluded that a $Y$ chromosome does not prevent a germ cell from developing into a functional oocyte.

\section{The sex chromosomes and germ cell fate in a testis}

XX germ cells in a testis.

In the early 1960s techniques were developed which enabled the aggregation of pairs of preimplantation mouse embryos and their subsequent development into single live " chimaeric » mice (Tarkowski, 1961 ; Mintz, 1962). Half of the pairs are $X X \leftrightarrow X Y$ combinations, and most of these develop as normal fertile males (McLaren, 1976). What is the fate of the $X X$ germ cells in these $X X \leftrightarrow X Y$ males ? Extensive breeding (996 offspring) from chimaeras in which the $X X$ and $X Y$ cell lines carried cell markers, has demonstrated that there are no progeny from the $X X$ cell line (Mystkowska and Tarkowski, 1968 ; Ford et al., 1974 ; McLaren, 1975). In an XX↔XY chimaera in which the strain combination allowed the identification of the source of the sperm using morphological criteria, no sperm from the $X X$ cell line were detected (Burgoyne, 1976). Furthermore, all spermatogonia, primary spermatocytes and secondary spermatocytes examined using suitable cytogenetic markers (a total of 855 spermatogenic cells) were derived from the XY cell line (Mystkowska and Tarkowski, 1968 ; Ford ef al., 1974). Clearly, XX germ cells do not survive into the aduli testis.

There is a considerable body of evidence supporting the generality of this conclusion. Thus adult $X X$ males (resulting from sex-reversal) in the mouse, goat and human (Cattanach, Pollard and Hawkes, 1971 ; Short, 1972 ; De La Chapelle, 1972) almost invariably lack germ cells in their testes. The only reports of $X X$ spermatogenic cells 
in adult testes (Benirshke and Brownhill, 1963 ; Hampton, 1973) have recently been questioned by Ford and Evans (1977).

The time course for $X X$ germ cell loss has been studied in sex-reversed mice and goats. Cattanach, Pollard and Hawkes (1971) found that 16 day mouse fetuses had an apparently normal complement of germ cells, but by the time of birth most were degenerating. A few underwent spermatogonial divisions, but by day 10 after birth, germ cell loss was complete. In the $X X$ male goat germ cell loss also begins late in gestation, and seems to be complete by the time of birth (Short, 1972).

$X X$ germ cells differ from $X Y$ germ cells in possessing an extra $X$ chromosome and in lacking a $Y$ chromosome. It must be one or other of these differences which is responsible for the death of $X X$ germ cells in a testis. Occasionally, small pockets of meiotic cells are found in the testes of adult $X X$ male mice, and cytogenetic analysis has shown that these meiotic cells are $X O$ (Lyon, 1974). Thus, the loss of the second $X$ by a disjunctional accident allows the germ cells to survive into the adult testis and enter meiosis. The death of testicular $X X$ germ cells must therefore be due to their having two $X$ chromosomes; implying that both $X$ s are functional, just as they are in oocytes.

\section{XO germ cells in a testis.}

Cattanach, Pollard and Hawkes (1971) have obtained XO males by introducing the sex-reversing mutation $S \times r$ into $X O$ mice. These $X O$ males proved to be sterile. Histological examination revealed that although there was spermatogenic activity throughout their testes, many of the spermatogenic cells degenerated during the meiotic stages, and few sperm were produced. However, these observations do not provide unequivocal answers as to the developmental potential of testicular XO germ cells, because the germ cells are $X O, S \times r$, raising the possibility that the $S \times r$ mutation is responsible for their partial success, or even their eventual failure. An $X O \leftrightarrow X Y$ chimaera would be a better model for testing the functional capacity of $X O$ germ cells in a testis, but attempts to produce these chimaeras have not been fruitful.

$X X Y$ germ cells in a testis.

If, as argued earlier, the presence of two $X$ chromosomes in a testicular germ cell leads to perinatal germ cell death, then $X X Y$ individuals should be sterile. This is indeed the case for all mammalian species in which $X X Y$ individuals have been identified (table 2). Some data on the timing of $X X Y$ germ cell loss is available for the human. In three boys aged 3, 4 and 12 months, Mikamo ef al. (1968) found the number of spermatogonia to be only 24,18 and 0.1 p. 100 of controls. In prepubertal boys aged 7-12 years (Ferguson-Smith, 1959) testicular biopsies revealed two types of tubules. Most lacked spermatogonia, but very occasionally fertile tubules were encountered. Fertile tubules are also occasionally found in Klinefelter men, especially when there is overt $X Y / X X Y$ mosaicism (Paulsen ef al., 1968). The present author is of the opinion that the fertile tubules in $X X Y$ boys and $X X Y$ men are the result of localised repopulation by $X Y$ germ cells, these having originated from $X X Y$ 
germ cells by disjunctional accidents (cf. $X O$ germ cells in the testes of $X X$ male mice). Contrary to this is the finding of $X Y$ and $X X Y$ spermatocytes in an $X X Y$ man by Skakkebaek, Philip and Hammen (1969) ; but the XXY spermatocyte illustrated was unconvincing and, as the authors admitted, the preparations were of poor quality. Meiotic studies of XXY men (with fertile tubules) using modern banding methods may eventually resolve this question.

TABLE 2

Mammalian XXYs

\begin{tabular}{|c|c|c|}
\hline Species & Testicular morphology (Adult) & References \\
\hline $\begin{array}{l}\text { Man } \\
\text { Cow } \\
\text { Sheep } \\
\text { Pig } \\
\text { Dog } \\
\text { Cat } \\
\text { Mouse } \\
\text { Wood lemming }\end{array}$ & $\begin{array}{l}\text { Small testes lacking } \\
\text { spermatogenic cells }\left({ }^{1}\right)\end{array}$ & $\begin{array}{l}\text { Review. Simpson, } 1976 \\
\text { Rieck, } 1970 \\
\text { Bruere, Marshall and Ward, } 1969 \\
\text { Breeuwsma, } 1968 \\
\text { Clough et al., } 1970 \\
\text { Centerwall and Benirschke, } 1975 \\
\text { Cattanach, } 1961 \\
\text { Gropp ef al., } 1976\end{array}$ \\
\hline
\end{tabular}

(1) Occasionally small pockets of spermatogenic cells are present.

Meiotic germ cells in the testes of fetal mouse chimaeras.

This discussion would be incomplete without mention of the meiotic cells which have been found in the fefal testes of $X X \leftrightarrow X Y$ mouse chimaeras (Mystkowska and Tarkowski, 1970). It should be pointed out that meiotic cells do not appear in normal testes until about two weeks after birth. The appearance of these fetal meiotic cells follows the time course for meiotic cells in the fetal ovary, and they lack the features (sex vesicle, late-labelling sex chromosomes) of meiotic germ cells in the normal adult testis (McLaren, Chandley and Kofman-Alfaro, 1972). It was therefore considered likely that these meiotic cells were $X X$ and not $X Y$. More recent work (Byskov and Saxén, 1976) has nevertheless shown that $X Y$ germ cells in the fetal mouse testis can enter meiosis in response to a meiotic inducer produced by contiguous fetal ovarian grafts. This inducer probably comes from the ovarian rete (Byskov, 1974). In the light of this it would be reasonable to suppose that in $X X \leftrightarrow X Y$ males there is localised production of the meiotic inducer by $X X$ (rete ?) cells, and that this causes germ cells in the vicinity to enter meiosis. This would explain why the germ cells follow the female schedule for entry into meiosis, but this interpretation would also predict that $X X$ and $X Y$ germ cells would enter meiosis. This is not necessarily at variance with the observations of McLaren, Chandley and Kofman-Alfaro (1972) because the absence of a sex vesicle and late-labelling sex chromosomes may reflect the immaturity of the meiotic cells, rather than their genotype. 
Germ cells in a testis - conclusions.

It is concluded that the correct $X$-dosage $(1 X)$ is essential for germ cells to survive in a testis. The question as to whether a germ cell must have a $Y$ chromosome in order to generate functional spermatozoa is still unresolved.

\author{
$27^{2}$ Congrès international des Sciences physiologiques, \\ Symposium " Germ and somatic cell interaction 》 \\ Paris, 21-23 juillet 1977.
}

Acknowledgments. - The author is grateful to the Medical Research Council (Great Britain) for a Research Fellowship, and for a travel grant.

Résumé. Une analyse est présentée sur les relations entre les anomalies de la différenciation des cellules germinales selon leur équipement en chromosomes sexuels. On doit conclure que les cellules germinales dans un ovaire nécessitent la présence de deux chromosomes $X$ actifs, pour que leur développement soit optimal. Les effets des déficiences dans le dosage de l'X sont plus sévères chez les espèces où se déroule une longue période de temps entre la formation et l'utilisation des ovocytes. Ainsi, les ovaires des XO (Turner) et des femmes $X Y$ sont invariablement vides d'ovocytes. Au contraire, les cellules germinales dans le testicule doivent seulement avoir un $X$ pour survivre. C'est pourquoi les mâles $X X$ ou XXY ont des testicules stériles.

\title{
References
}

BENIRSCHKE K., BROWNHILL L. E., 1963. Heterosexual cells in testes of chimeric marmoset monkeys. Cytogenetics, 2, 331-341.

BIANCHI N. O., CONTRERAS J. R., 1967. The chromosomes of the field mouse Akodon azarae (Cricetidae, Rodentia) with special reference to sex chromosome anomalies. Cytogenetics, 6 , 306-313.

BREEUWSMA A. J., 1968. A case of XXY sex chromosome constitution in an intersex pig. J. Reprod. Fert., 16, 119-120.

BRUERE A. N., MARSHALL R. B., WARD D. P. J., 1969. Testicular hypoplasia and XXY sex chromosome complement in two rams : the ovine counterpart of Klinefelter's syndrome in man. J. Reprod. Fert., 19, 103-108.

BURGOYNE P. S., 1976. Sperm phenotype and its relationship to somatic and germ line genotype : a study using mouse aggregation chimeras. Dev. Biol., 44, 63-76.

BURGOYNE P. S., 1978. The genetics of sex in development. In HAMILTON D. W., NAFTOLIN F., SHANE J., The essentials of human reproduction : a basis for clinical practice'. MIT Press, Cambridge U. S. A. (in press).

BURGOYNE P.S., BIGGERS J. D., (1976). The consequences of $X$-dosage deficiency in the germ line : impaired development in vitro of preimplantation embryos from XO mice. Dev. Biol., 51,109117.

BYSKOV A. G., 1974. Does the rete ovarii act as a trigger for the onset of meiosis ? Nature (Lond), 252, 396-397.

BYSKOV A. G., SAXÉN L., 1976. Induction of meiosis in fetal mouse testis in vitro. Dev. Biol., 52, 193-200.

CARR D. H., HAGGAR R. A., HART A. G., 1968. Germ cells in the ovaries of XO female infants. Am. J. clin. Poth., 49, 521-526.

CATTANACH B. M., 1961. XXY mice. Genet. Res. (Camb.), 2, 156-160.

CATTANACH B. M., 1962. XO mice. Genet. Res. (Comb.), 3, 487-490.

CATTANACH B. M., POLLARD C. E., HAWKES S. G., 1971. Sex-reversed mice : XX and XO males. Cytogenetics, 10, 318-337. 
CENTERWALL W. R., BENIRSCHKE K.. 1975. An animal model for the XXY Klinefelter's syndrome in man : tortoiseshell and calico male cats. Am. J. vet. Res., 36, 1275-1280.

CHANDLEY A. C., FLETCHER J., ROSSDALE P. D., PEACE C. K., RICKETTS S. W., MCENERY R. J., THORNE J. P., SHORT R. V., ALLEN W. R., 1975. Chromosome abnormalities as a cause of infertility in mares. J. Reprod. Fert. Suppl., 23, 377-383.

CLOUGH E., PYLE R. L., hARE W. C. D., KELLY D. F., PATTERSON D. F., 1970. An XXY sexchromosome constitution in a dog with testicular hypoplasia and congenital heart disease. Cytogenetics, 9, 71-77.

DE LA CHAPELLE A., 1972. Analytic review : nature and origin of males with $X X$ sex chromosomes. Am. J. hum. Genet., 24, 71-105.

EPSTEIN C. J., 1969. Mammalian oocyłes : X chromosome activity. Science, 163, 1078-1079.

EPSTEIN C. J., 1972. Expression of the mammalian $X$ chromosome before and after fertilization. Science, 175, 1467-1468.

EVANS E. P., FORD C. E., LYON M. F., 1977. Direct evidence of the capacity of the XY germ cell in the mouse to become an oocyte. Nature (Lond.), 267, 430-431.

FERGUSON-SMITH M. A., 1959. The prepubertal testicular lesion in chromatin-positive Klinefelter's syndrome (primary micro-orchidism) as seen mentally in handicapped children. Lancet, i, 219-222.

FORD C. E., EVANS E. P., 1977. Cylogenetic observations on XX/XY chimaeras and a reassessment of the evidence for germ cell chimaerism in heterosexual twin calves and marmosets. $J$. Reprod. Fert., 49, 25-33.

FORD C. E., EVANS E. P., BURTENSHAW M. D., CLEGG H., BARNES R. D., TUFFREY M., 1974. Marker chromosome analysis of tetraparental AKR $\leftrightarrow$ CBA-T6 mouse chimaeras. Differentiation, 2, 321-333.

FORD C. E., EVANS E. P., BURTENSHAW M. D., CLEGG H. M., TUFFREY M., BARNES R. D., 1975. A functional « sex-reversed » oocyte in the mouse. Proc. roy. Soc. Lond. B., 190, 187-197.

GARTLER S. M., ANDINA R., GANT N., 1975. Ontogeny of X-chromosome inactivation in the female germ line. Exp. Cell Res., 91, 454-457.

GARTLER S. M., LISKAY R. M., CAMPBELL B. K., SPARKES R., GANT N., 1972. Evidence for two functional $X$ chromosomes in human oocytes. Cell Diff., 1, 215-218.

GARTLER S. M., LISKAY R. M., GANT N., 1973. Two functional $X$ chromosomes in human fetal oocytes. Exp. Cell Res., 82, 464-466.

GOLDSTEIN J. L., WILSON J. D., 1974. Hereditary disorders of sexual development in man, 165173. In MOTULSKY A. G., LENZ W., Birth Defects. Excerpta Med., Amsterdam.

GROPP A., WINKING H., FRANK F., NOACK G., FREDGA K., 1976. Sex-chromosome aberrations in wood lemmings (Myopus schisticolor). Cytogenef. Cell Genet., 17, 342-358.

HAMPTON S. H., 1973. Germ cell chimerism in male marmosets. Am. J. Phys., Anthrop., 38, 265268.

HUGHES J. P., BENIRSCHKE K., KENNEDY P. C., TROMMERHAUSEN-SMITH A., 1975. Gonadal dysgenesis in the mare. J. Reprod. Fert. Suppl., 23, 385-390.

JIRASEK J. E., 1977. Morphogenesis of the genital system in the human. In Birth defects : Original Article Series, 13, 13-59, BLANDAU R. J., BERGSMA D., Morphogenesis and malformation of the genital system. A. R. Liss, New York.

KOZAK L. P., MCLEAN G. K., EICHER E. M., 1974. X-linkage of phosphoglycerate kinase in the mouse. Biochem. Genet., 11, 41-47.

LYON M. F., 1961. Gene action in the X-chromosome of the mouse (Mus musculus L.) Nature (Lond), 190, 372-373.

LYON M. F., 1974. Sex chromosome activity in germ cells, 63-71. In FUCHS F., CONTINHO E. M., Physiology and genetics of reproduction. Plenum, New York.

LYON M. F., HAWKER S. G., 1973. Reproductive lifespan in irradiated and unirradiated XO mice. Genet. Res. (Camb.), 21, 185-194.

MANGIA F., ABBO-HALBACH G., EPSTEIN C. J., 1975. X ehromosome expression during oogenesis in the mouse. Dev. Biol., 45, 366-368.

MCLAREN A., 1975. Sex chimaerism and germ cell distribution in a series of chimaeric mice. J. Embryol. exp. Morph., 33, 205-216.

MCLAREN A., 1976. Mammalian chimaeras. Cambridge Univ. Press. 154 pp. 
MCLAREN A., CHANDLEY A. C., KOFMAN-ALFARO S., 1972. A study of meiotic germ cells in the gonads of fotal mouse chimaeras. J. Embryol. exp. Morph., 27, 515-524.

MIGEON B. R., JELALIAN K., 1977. Evidence for two active $X$ chromosomes in germ cells of female before meiotic entry. Nafure (Lond.), 269, 242-243.

MIKAMO K., AGUERCIF M., HAZEGHI P., MARTIN-DU-PAIN R., 1968. Chromatinpositive Klinefelter's syndrome : a quantitative analysis of spermatogonial deficiency at 3,4 and 12 months of age. Fert. Steril., 19, 731-739.

MINTZ B., 1962. Experimental study of the developing mammalian egg : removal of the zona pellucida. Science, 138, 594-595.

MYSTKOWSKA E. T., TARKOWSKI A. K., 1968. Observations on CBA-p/CBA-T6T6 mouse chimaeras. J. Embryol. exp. Morph., 20, 33-52.

MYSTKOWSKA E. T., TARKOWSKI A. K., 1970. Behaviour of germ cells and sexual differentiation in late embryonic and early postnatal mouse chimaeras. J. Embryol. exp. Morph., 23, 395-405.

NORBY D. E., HEGREBERG G. A., THULINE H. C., FINDLEY D., 1974. An XO cat. Cytogenet. Cel. Genet., 13, 448-453.

OW. S., BAKER T. G., 1976. Initiation and control of meiosis in hamster gonads in vifro. J. Reprod. Fert., 48, 399-401.

OHNO S., 1963. Life history of female germ cells in mammals. Proc. 2nd Int. Conf. on Congenital Malformations, 36-42. Int. Med. Congr. Ltd, New York.

OHNO S., 1969. Evolution of sex chromosomes in mammals. Ann. Rev. Genet., 3, 495-524.

OHNO S., KAPLAN W. D., KINOSITA R., 1961. X-chromosome behaviour in germ and somatic cells of Raffus norvegicus. Exp. Cell Res., 22, 535-544.

OHNO, S., KLINGER H. P., ATKIN N. B. (1962). Human oogenesis. Cytogenetics, 1, 42-51.

OHNO S., WEILER C., 1961. Sex chromosome behaviour patterns in germ and somatic cells of Mesocricetus auratus. Chromosoma (Berl.), 12, 362-373.

PAULSEN C. A., GORDON D. L., CARPENTER R. W., GANDY H. M., DRUCKER W. D., 1968. Klinefelter's syndrome and its variants : a hormonal and chromosomal study. Rec. Progr. Horm. Res., 24, 321-353.

RIECK G. W., 1970. Das XXY syndrome beim Rind (Boviner hypogonadismus). Giessener Beitr Erbpath. Zuchthyg. Suppl. 1, 138-145.

SHARMA T., RAMAN R., 1971. An XO female in the Indian mole rat. J. Hered., 62, 384-387.

SHORT R. V., 1972. Germ cell sex, 325-345. In BEATTY R. A., GLUECKSOHN-WAELSH S., Edinburgh Symposium on the Genetics of the spermatozoon.

SIMPSON J. L., 1976. Disorders of sexual differentiation : etiology and clinical delineation. 472 pp. Acad. Press, New York.

SINGH R. P., CARR D. H., 1966. The anatomy and histology of XO human embryos and foetuses. Anat. Rec., 155, 369-384.

SKAKKEBAEK N. E., PHILIP J., HAMMEN R., 1969. Meiotic chromosomes in Klinefelfer's syndrome. Nature (Lond.), 221, 1075-1076.

TARKOWSKI A. K., 1961. Mouse chimaeras developed from fused eggs. Nature (Lond.), 190, 857-860.

WEISS G., WEICK R. F., KNOBIL E., WOLMAN S. R., GORSTEIN F., 1973. An X-O anomaly and ovarian dysgenesis in a rhesus monkey. Folia Primat., 19, 24-27.

YONG H. S., 1971. Presumptive $X$ monosomy in black rats from Malaya. Nature (Lond.), 232, 484-485. 